\title{
Orofacial granulomatosis: do not forget leishmaniasis
}

\author{
Imen Boukhris, Samira Azzabi, Eya Cherif, Ines Kechaou
}

Department of Internal Medicine, Charles Nicolle's Hospital, Tunis, Tunisia

\section{Correspondence to Dr Eya Cherif,} eyacherif@yahoo.fr

Accepted 9 August 2015
CrossMark

To cite: Boukhris I, Azzabi S, Cherif E, et al. BMJ Case Rep Published online: [please include Day Month Year] doi:10.1136/ bcr-2015-211919

\section{DESCRIPTION}

A 24-year-old man presented with a 1-year history of increasing swelling in the upper lip with a painful ulcer on the external oral mucosa. On physical examination, the upper lip showed swelling cheilitis, crusting and fissuring lesions. On the external fold of the upper lip, there were ulcerative lesions with necrotic and oedematous labial mucosa (figure 1A, B). The patient did not show any other clinical or biological abnormalities. Upper lip biopsy revealed organised non-caseating granulomas containing epithelioid cells and multinucleated giant cells surrounded by nodular inflammatory infiltrate composed of lymphocytes and plasma cells. A diagnosis of orofacial granulomatosis was made. Tuberculosis, sarcoidosis, Crohn's disease and lymphoma were eliminated as possible causes. Melkersson-Rosenthal syndrome and foreign body giant cell granuloma were also ruled out. Further microbiological investigations were carried out in order to locate the granulomatosis-causing agents. The serology for Leishmania spp was positive. PCR of an upper lip fragment confirmed the diagnosis of leishmaniasis. The patient was treated with intramuscular Glucantime for 20 days. The lesions steadily improved with total recovery (figure 2).

Proposed causes of orofacial granulomatosis include Crohn's disease, sarcoidosis, tuberculosis, foreign body giant cell granuloma and
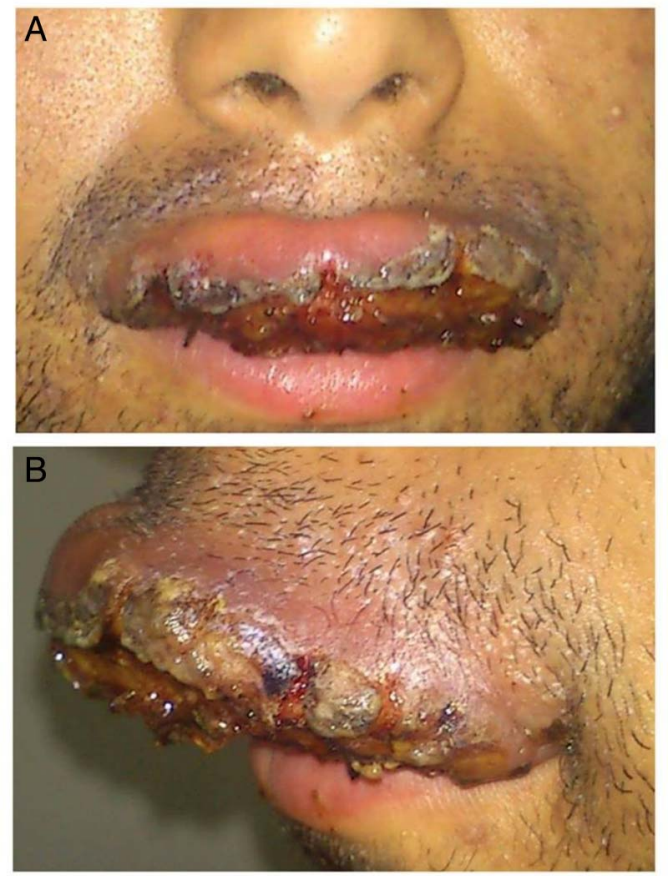

Figure 1 (A) and (B) Profile view showing swelling cheilitis, crusting and fissuring lesions.

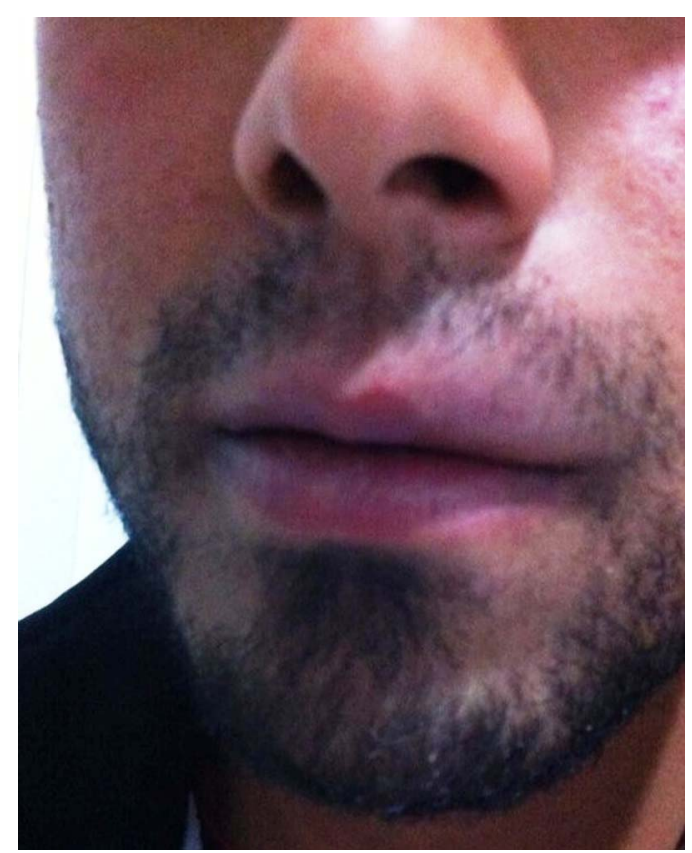

Figure 2 Evolution within a 12-week period.

Melkersson-Rosenthal syndrome. Other causes of granulomatous diseases must be investigated in order to find uncommon aetiologies. ${ }^{1}{ }^{2}$ Mucocutanous leishmaniasis most commonly affects the upper respiratory tract. Oral mucosa involvement is uncommon. As seen in this case, the efficacy of meglumine antimoniate for treatment of leishmaniasis is established. ${ }^{3}$

\section{Learning points}

- Clinician should bear in mind leishmaniasis in the differential diagnosis of orofacial granulomatosis.

- This case illustrates the need for an accurate and rapid diagnosis of leishmaniasis.

- Early diagnosis should prevent cosmetically disturbing cases.

Competing interests None declared.

Patient consent Obtained.

Provenance and peer review Not commissioned; externally peer reviewed.

\section{REFERENCES}

1 Critchlow WA, Chang D. Cheilitis granulomatosa: a review. Head Neck Pathol 2014;8:209-13.

2 Grave B, McCullough M, Wiesenfeld D. Orofacial granulomatosis-a 20-year review. Oral Dis 2009;15:46-51.

3 Mignogna MD, Celentano A, Leuci S, et al. Mucosal leishmaniasis with primary oral involvement: a case series and a review of the literature. Oral Dis 2015;21:e70-8. 
Copyright 2015 BMJ Publishing Group. All rights reserved. For permission to reuse any of this content visit http://group.bmj.com/group/rights-licensing/permissions.

BMJ Case Report Fellows may re-use this article for personal use and teaching without any further permission.

Become a Fellow of BMJ Case Reports today and you can:

- Submit as many cases as you like

- Enjoy fast sympathetic peer review and rapid publication of accepted articles

- Access all the published articles

- Re-use any of the published material for personal use and teaching without further permission

For information on Institutional Fellowships contact consortiasales@bmjgroup.com

Visit casereports.bmj.com for more articles like this and to become a Fellow 